\title{
China's private institutions for the education of health professionals: a time- series analysis from 1998 to 2012
}

\author{
Jianlin Hou', Zhifeng Wang ${ }^{2}$, Youhui Luo ${ }^{3}$, Joseph C. Kolars ${ }^{4}$ and Qingyue Meng ${ }^{2,5^{*}}$ (D)
}

\begin{abstract}
Background: Public institutions have been the major provider of education for health professionals in China for most of the twentieth century. In the 1990s, the Chinese government began to encourage the establishment of private education institutions, which have been steadily increasing in numbers over the past decade. However, there is a lack of authoritative data on these institutions and little has been published in international journals on the current status of private education of health professionals in China. In light of this knowledge gap, we performed a quantitative analysis of private institutions in China that offer higher education of health professionals.
\end{abstract}

Methods: Using previously unreleased national data provided by the Ministry of Education of China, we conducted time-series and descriptive analyses to study the scale, structure and educational resources from 1998 to 2012 of private institutions for health professional education.

Results: The number of private institutions that educate health professionals increased from two in 1999 to 123 in 2012. Private institutions displayed an average annual growth rate of $44.2 \%$ for enrolment, $59.0 \%$ for the number of students and 53.3\% for the number of graduates. In 2012, nursing, clinical medicine and traditional Chinese medicine had the most students (37.2\%, 32.8\% and 8.9\% respectively), representing $78.9 \%$ of all students in these institutions. Ninety-seven private institutions located in the more economically advantaged eastern and central China and only 26 ones were in the less economically advantaged western China, respectively turning out $85.2 \%$ and $14.8 \%$ of health professional graduates. There were less educational resources, such as the number of faculty members, physical space and assets, at private institutions than at public institutions.

Conclusions: Private institutions for the education of health professionals have emerged quickly in China, contributing to the demand for health professionals that exceeds what public institutions are able to offer. At the same time, the imbalance of geographical distribution and poor educational resources of private institutions are of concern. It may be of utmost importance to enhance administration and supervision to better regulate private institutions and their development plans. Future studies may be needed to better examine the effects of private institutions on the production and allocation of health workers.

Keywords: Private education institution, Education of health professionals, Scale of education, Structure of education, Educational resources, China

\footnotetext{
* Correspondence: qmeng@bjmu.edu.cn

${ }^{2}$ School of Public Health, Peking University, Beijing, China

${ }^{5}$ China Center for Health Development Studies, Peking University, No. 38

Xueyuan Road, Beijing 100083, China

Full list of author information is available at the end of the article
}

(c) The Author(s). 2018 Open Access This article is distributed under the terms of the Creative Commons Attribution 4.0 International License (http://creativecommons.org/licenses/by/4.0/), which permits unrestricted use, distribution, and reproduction in any medium, provided you give appropriate credit to the original author(s) and the source, provide a link to the Creative Commons license, and indicate if changes were made. The Creative Commons Public Domain Dedication waiver (http://creativecommons.org/publicdomain/zero/1.0/) applies to the data made available in this article, unless otherwise stated. 


\section{Background}

The high cost of educating health professionals is a major issue for public institutions that provide higher education. By allowing private capital into this sector, the government's financial burden is reduced and the number of health profession graduates can increase without further public investment. Globally, the contribution of private institutions to the education of health professionals varies among countries and regions [1]. In many countries, non-profit and for-profit private education institutions have become an important component for health-professional education and often account for the greatest area of growth. For example, most of the new medical schools built in India since the 1970s were private institutions [1]. And the first private medical school in Sub-Saharan Africa was founded in 1990 where private medical schools now account for $26 \%$ of all medical schools [2]. In other countries such as the United States of America and Japan, private medical schools account for a sizable portion of the accredited medical schools that offer terminal degrees [3, 4]. Also, in the United Kingdom, the first private medical school began admitting students in 2015, followed by an intention to start another private medical school by a public university [5].

In China, private medical schools were first established by missionaries from western countries in the mid-nineteen century $[6,7]$. After the founding of the People's Republic of China in 1949, the government took over control of all public and private education institutions. Subsequently, private institutions were closed or transformed into public institutions which exclusively oversaw the education of health professionals for nearly half a century. In October 1997, China's State Council issued new Regulations on the Running of Education Institutions with Social Resources which encouraged the further development of private education institutions while maintaining strict control over the regulatory aspects of higher education [8]. After 2003, with the implementation of Private Education Promotion Law of the People's Republic of China, followed by The Regulation on the Implementation of the Private Education Promotion Law of the People's Republic of China, individuals and non-governmental sectors were encouraged to invest in education. With the removal of restrictive regulations, the number of private institutions offering health professional education increased rapidly [9]. According to laws and regulations in China, private education belongs to the public and their welfare and, therefore, should not be for profit. However, those providing the financial capital were allowed to "obtain a reasonable amount of requital from the surplus" after the "cost of a private school is deducted...and the sum of money for other necessary expenses is drawn in accordance with the relevant regulations of the State" [10].
At present, private institutions in China that offer higher education for future health professionals are established through two different approaches which are typically complex with regard to how they were established, ownership and models of operation [9]. The first approach consists of entities such as individuals, social groups, or a school offering a major of applied techniques (e.g. rehabilitation, acupuncture) at the level of higher vocational training leading to the equivalent in the West of a junior college degree (i.e. Da Zhuan in China). The other approach consists of a public university or college establishing a private arm of the institution, often referred to as an "independent school," that most typically offers an undergraduate education programme leading to a bachelor degree [9]. Public universities following this second approach commonly partner with other parties, such as local governments, enterprises, individuals and social groups to establish an independent school [11]. The Ministry of Education (MOE) of China issued Measures for the Establishment and Administration of Independent Schools in 2008, which defines independent schools as "schools engaging in undergraduate education which are jointly established by regular universities and colleges engaging in undergraduate education or above with non-government sectors or individuals with funding from sources other than national finance" [12].

Historically, government funding in China supported public education. On rare occasions, private institutions draw government funding which is usually extremely small. Due to the lack of preferential tax policies for donors, donation revenues for private education institutions are limited. Only a few private institutions offering health profession education have relatively sufficient funding. These institutions employ experienced administrative and teaching staff from public universities and are therefore more familiar with modern management systems and problem-solving abilities compared to other private institutions. These institutions with sufficient funding and staff have demonstrated their contributions to the education of health professionals in China [1315]. However, due to the lack of funding as well as a strong profit orientation, investments in human and material resources by many other private institutions are insufficient, resulting in deficiencies across their education systems.

First, most private institutions generally offer poor remuneration making it difficult to attract and retain quality faculty members. Many of these are full-time employees of public institutions who only teach at private institutions on a part-time basis. With a high turnover rate and a large percentage of part-time faculty, private institutions are unable to compete with public institutions in terms of academic research and teaching 
quality $[16,17]$. Private institutions are also challenged to define their discipline and curriculum while staying up-to-date with education reform in the country [1618]. Second, in addition to the lack of teaching materials, many laboratories at private institutions are in poor conditions and cannot accommodate the practical learning needs of their students. Some private institutions also lack proper infrastructure and buildings, such as classrooms and dormitories [19-21]. Third, clinical teaching bases (e.g. affiliated or teaching hospitals) are often not accessible to students who attend private institutions. Due to high construction cost, many private medical schools do not have their own affiliated or teaching hospitals, which poses substantial inconveniences for clinical teaching and training [19, 21-24]. All of these issues contribute to the failure of private institutions' ability to deliver rigorous, high-quality education, perpetuating negative stereotypes towards private education of health professionals, resulting in local government unwilling to provide support [25]. In addition, faculty from private institutions is not held in high regard when competing with faculty from public institutions for positions [20]. There is also discrimination against health professional graduates from private institutions, which is reflected in hiring policies or standards established by some local governments in the recruitment of public servants [26-28].

Even though private institutions that train health professionals have been developing for over a decade in China, little has been documented in the literature. Domestic studies have been primarily qualitative descriptions or with students as study objects. To the best of our knowledge, there is a lack of authoritative statistics and analyses on the nationwide development of private institutions for the education of health professionals in China, particularly in international peer-reviewed journals. In the present study, we aimed to use national data to conduct a quantitative analysis of the scale, structure and educational resources of the private institutions offering higher education of health professionals. Furthermore, we sought to compare private and public institutions in terms of their changes in higher education of health professionals, educational resources and relative contribution to the production of health workers. In the following sections of the paper, we described the data and analysis method used in the study, presented results of data analysis, discussed policy implications of the findings and summarized major conclusions.

\section{Methods}

The data used in this study are previously unreleased national routine data provided by the MOE of China, including the (1) number of health professional students by school and major degree and (2) statistics on faculty and staff size, assets and physical space by school. Descriptive analysis was performed from datasets generated from yearly statistical forms between 1998 and 2012 that each higher education institution submits to the MOE and local education authorities. Select aggregate results of these forms are accessible to the public, but no national statistics on private institutions for the education of health professionals have been released. The datasets that we obtained from the MOE consist of all institutions offering higher education of health professionals. The total number of students and faculties in the datasets equal those in the aggregate results that are assessable to the public. The complete and accurate MOE datasets enable us to define the quantitative characteristics of these institutions and their changes in the country.

The focus of our analysis within the MOE datasets is private regular institutions offering higher education of health professionals. Regular is defined as educational institutions with health science majors including all of the following 11 first-level disciplines in the education of health professionals: basic medicine, clinical medicine, pharmacy, public health and preventative medicine, nursing, traditional Chinese medicine (TCM), stomatology, medical techniques, Chinese pharmacy, forensic medicine and integrated Chinese and western medicine. These institutions provide programmes that lead to a junior college (i.e. Da Zhuan), bachelor, master, or doctorate degree. The length of the education programmes varies from 3 to 8 years.

China's higher educational institutions (HEIs) consist of regular HEIs and HEIs for adults [29]. Typically, the former admits high school graduates as full-time students through the national college entrance examination, while the latter provides adults with higher education on a part-time basis through distance education or some on-campus courses. There was only one private HEI for adults in 2015, according to statistics from the Ministry of Education of China. Only private regular HEIs are included in our analysis because they are dominant in and most representative of China's higher education of health professionals.

\section{Results}

\section{Overall scale of education and its changes}

As noted in Table 1, since the emergence of two private colleges in 1999, the total number has increased to 123 in 2012 , accounting for $20.8 \%$ of all institutions offering higher education of health professionals. Total enrolment in these private institutions rose from 745 in 1999 to 86501 in 2012. The total number of health professional students surged to 310386 compared with 745 in 1999, while the number of graduates climbed up to 70 868 in contrast to 991 in 2002. During the time span of 1999 to 2012, private institutions were seeing an average annual growth rate of $44.2 \%$ for enrolment, $59.0 \%$ for 
Table 1 Number and percentage of private and public education in China's higher education system of health professionals: 19982012

\begin{tabular}{|c|c|c|c|c|c|c|c|c|}
\hline \multirow[b]{2}{*}{ Year } & \multicolumn{2}{|l|}{ Institution } & \multicolumn{2}{|c|}{ Total number of enrolments } & \multicolumn{2}{|c|}{ Total number of students } & \multicolumn{2}{|c|}{ Total number of graduates } \\
\hline & Private & Public & Private & Public & Private & Public & Private & Public \\
\hline 1998 & $0(0.0)$ & $189(100.0)$ & $0(0.0)$ & $82138(100.0)$ & $0(0.0)$ & $301866(100.0)$ & $0(0.0)$ & $65916(100.0)$ \\
\hline 1999 & $2(1.0)$ & 207 (99.0) & $745(0.6)$ & $116117(99.4)$ & $745(0.2)$ & 350078 (99.8) & $0(0.0)$ & $66763(100.0)$ \\
\hline 2000 & $3(1.1)$ & $261(98.9)$ & $941(0.6)$ & 160241 (99.4) & $1505(0.3)$ & 448939 (99.7) & $0(0.0)$ & $65682(100.0)$ \\
\hline 2001 & $4(1.4)$ & 282 (98.6) & $3153(1.7)$ & 186706 (98.3) & $5263(0.9)$ & 560883 (99.1) & $0(0.0)$ & $69259(100.0)$ \\
\hline 2002 & $20(6.3)$ & $295(93.7)$ & $7384(3.3)$ & $214896(96.7)$ & $13854(2.0)$ & $680497(98.0)$ & $991(1.1)$ & $85835(98.9)$ \\
\hline 2003 & $60(15.4)$ & $330(84.6)$ & $22191(8.0)$ & 254800 (92.0) & $43270(5.0)$ & 820645 (95.0) & $1576(1.3)$ & $119340(98.7)$ \\
\hline 2004 & $86(19.0)$ & $366(81.0)$ & 34911 (10.9) & 285373 (89.1) & 78208 (7.6) & 950845 (92.4) & $4969(3.0)$ & 162105 (97.0) \\
\hline 2005 & 98 (20.9) & 372 (79.1) & $50010(13.7)$ & 315026 (86.3) & 118835 (9.9) & 1081519 (90.1) & 7615 (3.5) & 208562 (96.5) \\
\hline 2006 & $103(21.1)$ & $384(78.9)$ & $52922(12.9)$ & 357326 (87.1) & 152484 (11.3) & 1196932 (88.7) & 15980 (5.9) & 254867 (94.1) \\
\hline 2007 & $112(21.7)$ & $405(78.3)$ & $59404(14.9)$ & 339281 (85.1) & 193810 (13.1) & 1285656 (87.9) & 27460 (8.5) & 295599 (91.5) \\
\hline 2008 & $110(21.4)$ & 405 (78.6) & 66052 (15.3) & 365660 (84.7) & 222145 (13.7) & 1399351 (86.3) & 40447 (10.2) & $356092(89.8)$ \\
\hline 2009 & $105(20.2)$ & $416(79.8)$ & 78501 (16.1) & 409083 (84.9) & 255331 (14.6) & 1493511 (85.4) & $49714(12.0)$ & 364569 (88.0) \\
\hline 2010 & $110(20.4)$ & $429(79.6)$ & 80062 (15.3) & 443219 (84.7) & 274650 (14.6) & $1606514(85.4)$ & $60344(12.9)$ & $407439(87.1)$ \\
\hline 2011 & 119 (20.9) & 451 (79.1) & 84309 (14.4) & 499334 (85.6) & 294534 (14.9) & 1677040 (85.1) & 65877 (13.5) & 420761 (86.5) \\
\hline 2012 & $123(20.8)$ & 467 (79.2) & 86501 (14.7) & $500036(85.3)$ & 310386 (14.8) & 1793241 (85.2) & 70868 (14.0) & $436790(86.0)$ \\
\hline
\end{tabular}

Note: percentages in parenthesis

number of students and $53.3 \%$ for number of graduates, significantly higher than public ones $(11.9 \%, 13.4 \%$ and $15.5 \%$ respectively). As for percentages in the education of health professionals, private institutions were also seeing a yearly increase, with percentage of enrolment, students and graduates respectively reaching 14.7\%, 14.8\% and $14.0 \%$ in 2012.

From 1999 to 2012, the average enrolment of private institutions increased from 373 to 703 . In the same period, the average enrolment of public institutions rose from 561 to 1071 . Except for 2001, the average enrolment of private institutions was less than that of public ones (Fig. 1).

\section{Structure of education}

Independent schools, namely private arms of public universities or colleges, grew faster than other kinds of private institutions. Among 123 private institutions in 2012, 57 (46.3\%) were independent schools, 37 (30.1\%) were higher vocational schools and 24 (19.5\%) were colleges. Undergraduate education was available in 76 (61.8\%) private institutions while $78(63.4 \%)$ ones offered junior college education. None of the 123 institutions has master or doctoral programmes, indicating that private education of health professionals is limited to junior college and undergraduate level.

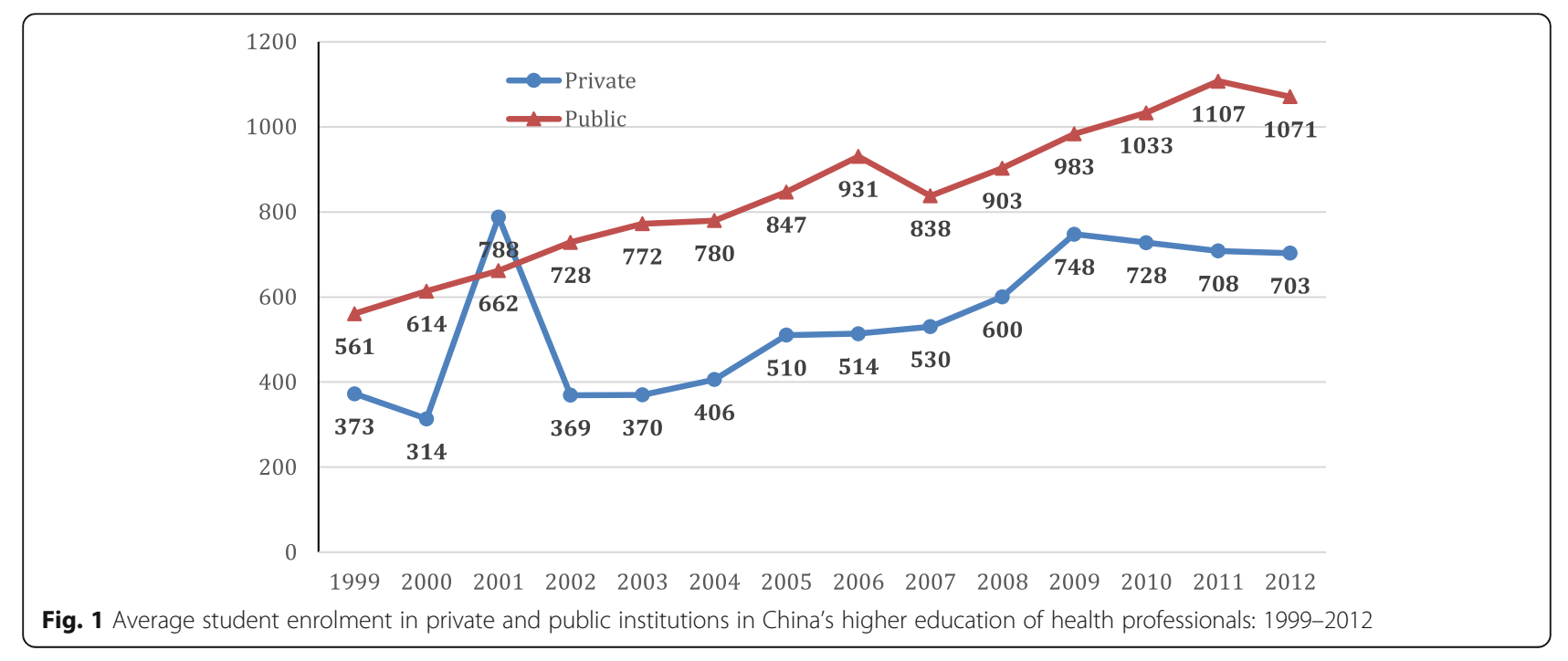


Of the 123 institutions, 61 were in eastern China, 36 in central China and 26 in western China, respectively turning out $53.7 \%, 31.5 \%$ and $14.8 \%$ of health professional graduates. Eastern China has the most private education institutions and graduates, central China less and western China least. Such geographical distribution pattern is the same with public education institutions (Table 2).

Private institutions do not put as much emphasis on research programmes or on preparation for academic careers as much as public institutions. Instead, they focus on the education of health professionals that are popular and have a promising career prospection, or offer programmes with a low cost or requirement of educational resources, such as nursing, TCM and the education of practical clinical professionals for rural areas and regions of lower administrative level (usually referred to as "grass-root level") [22, 25, 30, 31].

In 2012, nursing, clinical medicine and TCM have the most students $(37.2 \%, 32.8 \%$ and $8.9 \%$ respectively), adding up to $78.9 \%$ of all students in private institutions. In terms of percentage of private health professional students nationwide by major, it is stomatology $(22.6 \%)$, integrated Chinese and western medicine (20.4\%) and TCM (17.9\%) that prevail (Table 3).

As for health professional graduates nationwide by major, private institutions were seeing a relatively large proportion in stomatology (25.6\%), integrated Chinese and western medicine (17.3\%) and nursing (16.4\%). By contrast, a majority of health professional graduates were turned out by public institutions in all of the 11 majors with the biggest three percentages found in basic medicine (100\%), public health and preventive medicine (98.5\%) and forensic medicine (97.1\%) (Fig. 2). Such discipline distribution is similar to health professional enrolment (Fig. 3).

\section{Educational resources}

Education resources largely decreased in private institutions from 1999 to 2012, except multi-media classroom seats per hundred students. Specifically, student-faculty ratio increased more than fourfold, from 5.2:1 to 23.9:1. Gross value of fixed assets per student fell from 439000 yuan to 40000 yuan (i.e. 67518 to 6152 in 2016 US dollars). Value of teaching and research devices and equipment per student decreased from 19000 yuan to 7 000 yuan (i.e. 2922 to 1077 in 2016 US dollars) (Table 4).

As noted in Table 5, private institutions do not compare favourably with public ones, in nearly all primary educational resource indicators.

\section{Discussion}

Since 1999, private institutions have emerged and expanded to about one fifth of all institutions that educate health professionals in China. As of 2012, they accounted for nearly one seventh of the country's health professional graduates. These private institutions have made significant contributions to the education of health professionals in shortage areas. We also show the impact of private institutions on specific cadre. For example, dental, TCM and nursing students of private institutions respectively accounted for $22.6 \%, 18.5 \%$ and $17.5 \%$ of students in the whole country in 2012.

As observed in India and many other countries, government investment on public education institutions alone could not keep up with the increasing demand for the education of health professionals [1-4]. With public education institutions having a history of more than 60 years in China, more attention may need to be placed on supporting and standardizing private institutions if they are expected to play a more meaningful role in producing health professionals for China. Funding is the vital material foundation for the development of any education. Like private medical schools in Africa and other places [2], the financial viability of private institutions in China mainly relies on investment of the operators and revenues from tuition fees. Although the primary data we could access does not report on the tuition or entrance college examination scores, the literature suggests that private institutions typically have higher tuition rates and lower entrance examination scores relative to their public institution counterparts $[26,32]$. Therefore, some students choose to study in private institutions when they do not gain admittance to public ones. It was reported that private institutions in many provinces increased their tuition by about $30 \%$

Table 2 Geographical distribution of private and public education institutions and their health professional graduates in China: 2012

\begin{tabular}{|c|c|c|c|c|c|c|}
\hline & \multirow{2}{*}{$\begin{array}{l}\text { GDP } \\
\text { per } \\
\text { capita } \\
\text { (yuan) }\end{array}$} & \multirow{2}{*}{$\begin{array}{l}\text { Total } \\
\text { population } \\
\text { (million) }\end{array}$} & \multicolumn{2}{|l|}{ Institution } & \multicolumn{2}{|l|}{ Graduate } \\
\hline & & & Private & Public & Private & Public \\
\hline Eastern & 57429 & $558.5(41.4)$ & $61(49.6)$ & $200(42.8)$ & $38040(53.7)$ & $183651(42.0)$ \\
\hline Central & 33382 & $425.1(31.5)$ & $36(29.3)$ & $159(34.0)$ & 22334 (31.5) & $159443(36.5)$ \\
\hline Western & 31269 & $364.3(27.0)$ & $26(21.1)$ & $108(23.1)$ & $10494(14.8)$ & $93696(21.5)$ \\
\hline Total & 42580 & $1347.9(100.0)$ & $123(100.0)$ & 467 (100.0) & 70868 (100.0) & $436790(100.0)$ \\
\hline
\end{tabular}

Note: Data source for GDP per capita and total population: China Statistical Yearbook 2013; percentages in parenthesis 
Table 3 Health professional students of private education institutions by major in 2012

\begin{tabular}{llll}
\hline Major & $N$ & Percent & $\begin{array}{l}\text { \% of students in } \\
\text { the whole country }\end{array}$ \\
\hline Nursing & 115550 & 37.2 & 17.5 \\
Clinical medicine & 101863 & 32.8 & 13.9 \\
TCM & 27593 & 8.9 & 17.9 \\
Pharmacy & 18329 & 5.9 & 10.2 \\
Stomatology & 16393 & 5.3 & 22.6 \\
Medical techniques & 15536 & 5.0 & 11.9 \\
Integrated Chinese and western & 9326 & 3.0 & 20.4 \\
medicine & & & \\
Chinese pharmacy & 4736 & 1.5 & 7.9 \\
Public health and preventative & 920 & 0.3 & 1.8 \\
medicine & & & \\
Forensic medicine & 140 & 0.0 & 2.6 \\
Basic medicine & 0 & 0.0 & 0.0 \\
Total & 310386 & 100.0 & 14.8 \\
\hline
\end{tabular}

or $50 \%$ in the past few years because they were allowed to set criteria of tuition fees by themselves, discouraging students from choosing to study in these institutions [33-35]. An additional financial burden that is often hidden relates to the fact that many students extended their high school period for a year or more in order to better prepare the college entrance examination and gain admittance to a public institution [3335]. It will be essential for private institutions to set up a multi-channel and effective fund-raising system. In addition, the government should issue and implement policies of financial support for private institutions in accordance to the rule of health professional education, such as preferential tax policies for donors, supportive policies for application of research funding and tax reduction or exempt.

Worldwide, the distribution of medical schools has been closely associated with economic performance, which means that more developed regions tend to have more medical schools [1]. Such distribution patterns are also applicable in China. As shown in Table 2, there were more private education institutions and health professional graduates from the more economically advantaged eastern and central regions of China. We found 97 private institutions located in these two regions and only 26 ones were in the less economically advantaged western China, respectively turning out $85.2 \%$ and $14.8 \%$ of health professional graduates. Parameters of health in western China are lower as are the allocation of human resources for health. For example, there are only 1.7 registered nurses per 1000 population in western China, compared with 2.0 in eastern China and 1.8 in central China.

Western China would benefit from efforts to strengthen the local education of health professionals. In 2012, the number of health-professional education institutions per ten million people in western China was 3.7, compared with the eastern (4.8) and central (4.6) regions of the country. Health professional graduates per hundred thousand people in the west were less 28.6, compared with the eastern (41.1) and central (43.1) regions [36]. If China does not increase investments for public institutions in the western areas, private institutions may attempt to fill this gap.

Educational resources are of utmost importance to guaranteeing the supply and quality of education [37, 38]. Education of health professionals often means a need for better educational resources. As the scale of education goes up, education institutions for health professionals in China are seeing a decline in educational

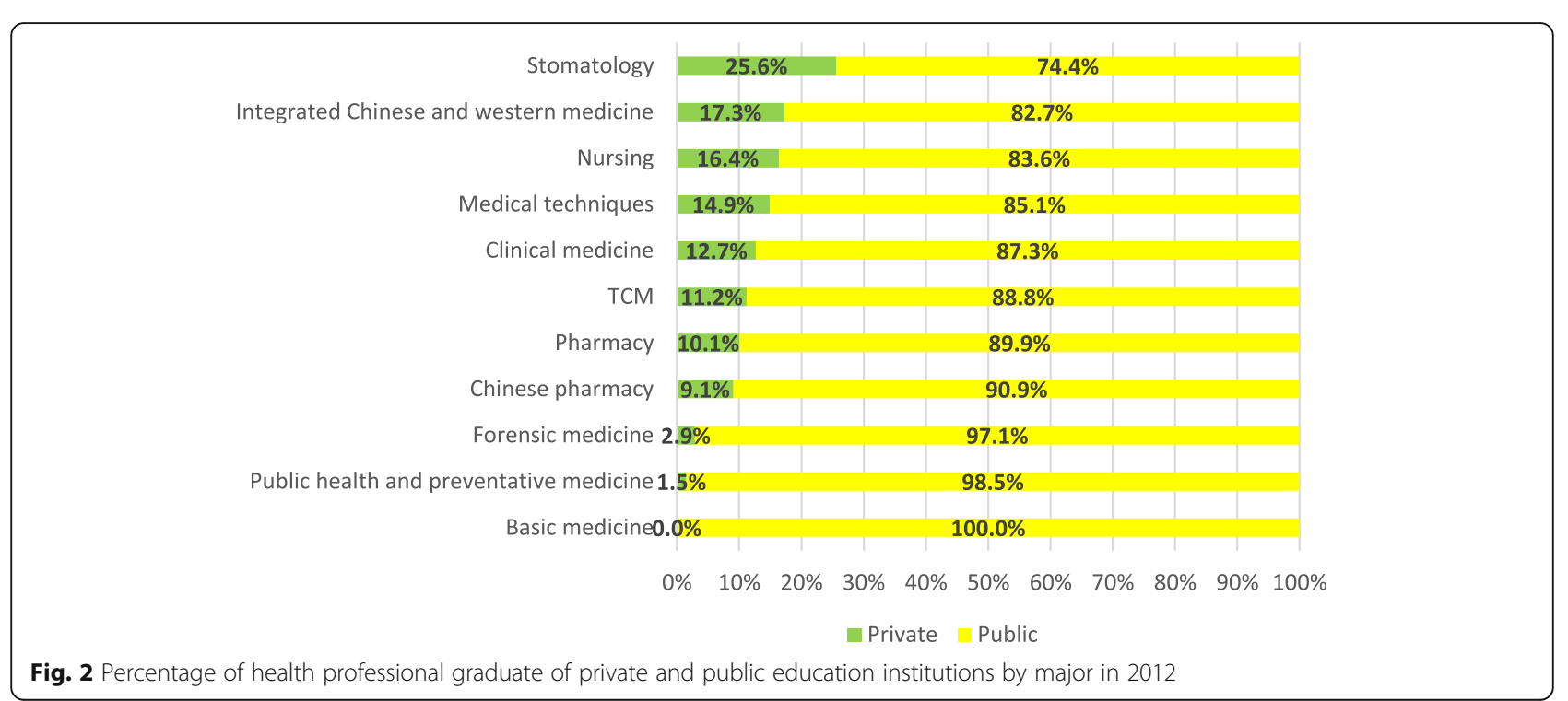




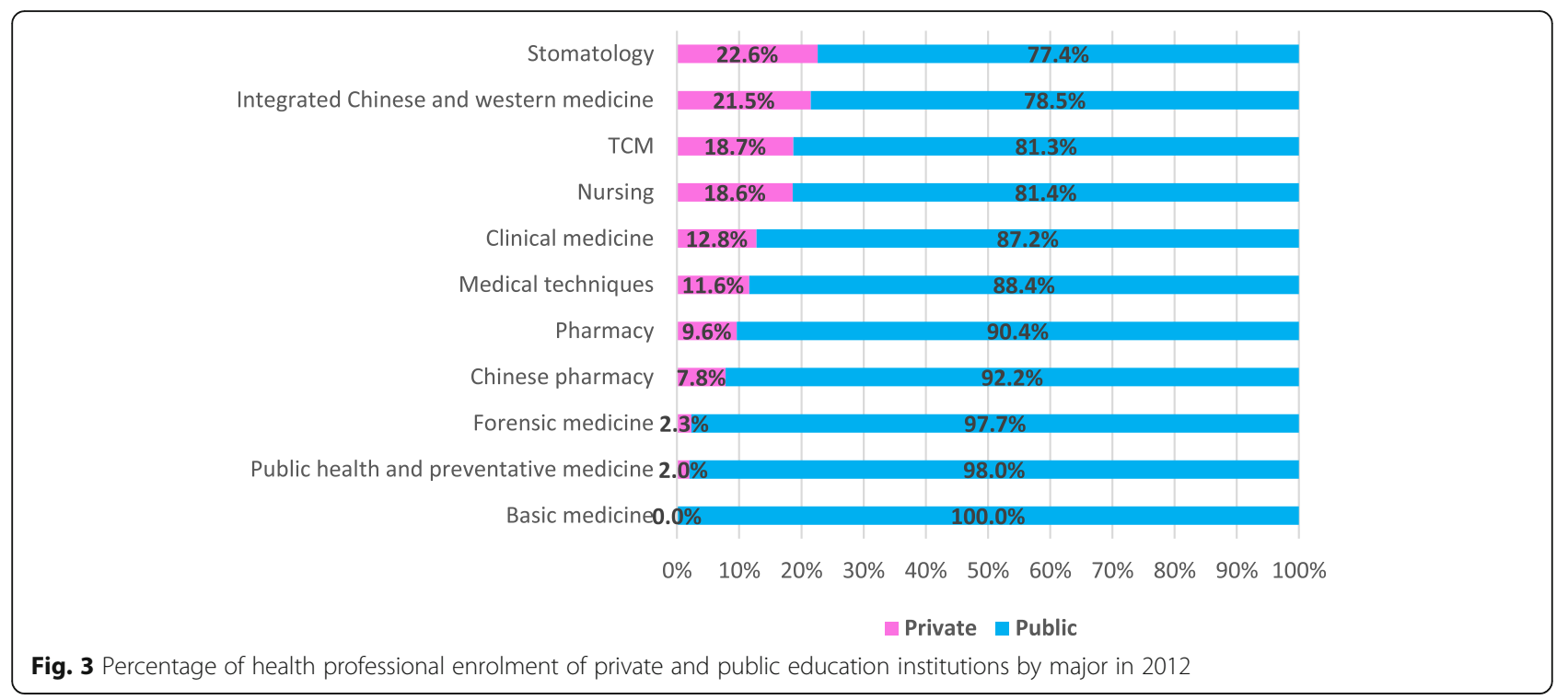

resources, with per student educational resources reduced or hardly increased [39-41], in wake of which that of private institutions are least assuring. Therefore, in sacrificing needed educational resources for profits, private institutions for the education of health professionals might go farther than public ones. The assurance of educational resources and education quality calls for governmental guidance and supervision. Government should make clear basic requirements for establishment and be strict with the examination and approval of private education institutions, thus laying the foundation for education quality. At the same time, different regions may need to be treated differentially. For less developed regions, requirements for establishment may be compromised for the actual circumstances to a reasonable extent.

Although private institutions play an increasing role in the education of health professionals in China, their strong motives for profits, variability in quality and uneven distribution across the country raise concerns. To better regulate private institutions and their development plans, it may be of utmost importance to enhance administration and supervision, especially through enhancing accreditation of institutions and programmes to ensure that they meet a set of established standards [42, 43]. In the past few years, accreditation entities and mechanism have been established for several undergraduate programmes (e.g. medicine and nursing) in China. To date, only a few medical programmes of private institutions have been accredited though the MOE plans to complete first-round accreditation of all medical programmes by 2020 are in place.

This current descriptive analysis of private health profession schools in China leads to other important questions that should be pursued; the most important of which are the percentage of these graduates actually enter the health workforce and how they perform as health care professionals. Future studies should also examine where these graduates are practicing and their ability to secure position they desire. Qualitative studies including interviews with students, graduates, faculty and administrators of private institutions as well as with government officials are necessary to better interpret the quantitative data presented in this paper.

Although we present data from a unique dataset from the MOE in China, several limitations are worth noting. First, the datasets contain only the number of full-time faculty and not those who teach on a part-time basis. Therefore, the student-teacher ratio calculated in the study may be higher if this part-time faculty could be considered. Second, private institutions, especially in their early stages of development, may lack the staff and expertise regarding data, thereby limiting data quality. As it is difficult to address such issues when using national routine data, a sampling study and field survey of private institutions may be needed to further refine findings in the study.

Finally, some most recent developments regarding private institutions are also worth mentioning. With the investment of foreign capital and involvement from top international universities, some China-based overseas educational institutions such as Duke Kunshan University have recently emerged but not included in the data set. These models involve collaborations between public institutions in China and foreign schools that typically receive funding (e.g. land, infrastructure) from local government. These institutions operate privately and have the potential to contribute significantly to health profession education in China as they are capable of offering world-class quality of education. In this sense, they differ from the "traditional" private institutions we analysed in the paper. 


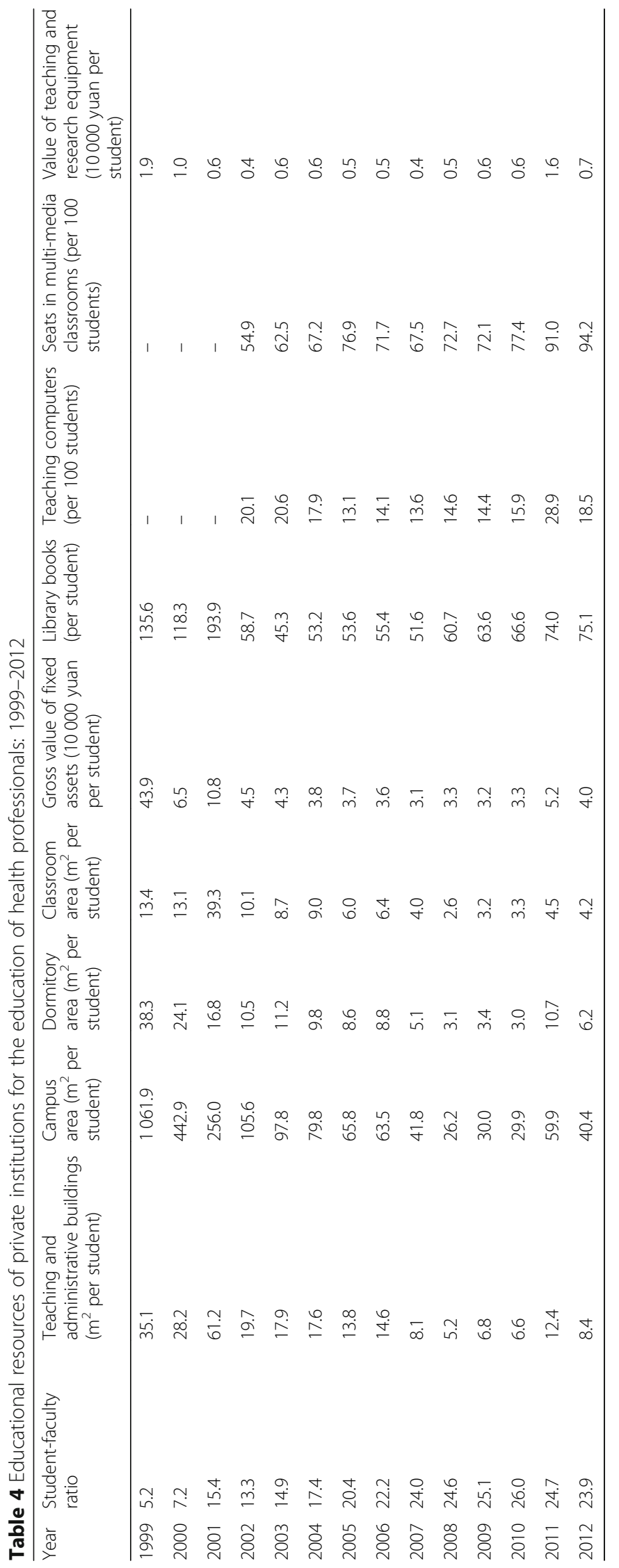


Table 5 Comparison of educational resources between private and public institutions for the higher education of health professionals

\begin{tabular}{|c|c|c|c|c|c|c|c|}
\hline & \multicolumn{3}{|l|}{2012} & \multirow[t]{2}{*}{$\begin{array}{l}\text { National } \\
\text { standard }^{1}\end{array}$} & \multicolumn{3}{|c|}{$\begin{array}{l}\text { Average rate of change (\%): } \\
\text { 1998-2012 }\end{array}$} \\
\hline & Private & $\begin{array}{l}\text { Public (central } \\
\text { government) }\end{array}$ & $\begin{array}{l}\text { Public } \\
\text { (others) }\end{array}$ & & Private & $\begin{array}{l}\text { Public (central } \\
\text { government) }\end{array}$ & $\begin{array}{l}\text { Public } \\
\text { (others) }\end{array}$ \\
\hline Student-faculty ratio & 23.9 & 12.8 & 20.3 & 16.0 & 11.5 & 7.1 & 5.5 \\
\hline Campus area ( $\mathrm{m}^{2}$ per student) & 40.4 & 81.5 & 70.0 & 59.0 & -20.9 & -1.6 & -0.3 \\
\hline Teaching and administrative buildings ( $\mathrm{m}^{2}$ per student) & 8.4 & 16.0 & 14.6 & 16.0 & -9.3 & 1.2 & 0.8 \\
\hline Classroom area ( $m^{2}$ per student) & 4.2 & 3.2 & 5.3 & - & -8.3 & 2.2 & 2.3 \\
\hline Dormitory area ( $\mathrm{m}^{2}$ per student) & 6.2 & 14.6 & 11.2 & 6.5 & -12.3 & 11.7 & 8.3 \\
\hline Gross value of fixed assets (10 000 yuan per student) & 4.0 & 8.1 & 4.4 & - & -16.0 & 9.6 & 9.2 \\
\hline Library books (volume per student) & 75.1 & 80.0 & 67.9 & $60 / 80$ & -4.5 & -2.4 & -1.9 \\
\hline Teaching computers (per 100 students) ${ }^{2}$ & 18.5 & 34.7 & 25.3 & $8.0 / 10.0$ & -0.8 & 6.5 & 11.3 \\
\hline Seats in multi-media classrooms (per 100 students) ${ }^{3}$ & 94.2 & 95.6 & 91.5 & 7.0 & 7.2 & 18.2 & 21.1 \\
\hline $\begin{array}{l}\text { Value of teaching and research devices and equipment } \\
\text { (10 000 yuan per student) }\end{array}$ & 0.7 & 3.4 & 1.2 & $0.4 / 0.5$ & -7.4 & 18.5 & 10.8 \\
\hline
\end{tabular}

${ }^{1}$ Ministry of Education of China, 《Qualification indicator of educational resources for universities and colleges》, 2004

${ }^{2,3}$ Average rate of change for year 2002 to 2012 were calculated

\section{Conclusions}

Private institutions for the education of health professionals have emerged quickly in China, contributing to the demand for health professionals that exceeds what public institutions are able to offer. At the same time, the imbalance of geographical distribution and poor educational resources of private institutions are of concern. It may be of utmost importance to enhance administration and supervision to better regulate private institutions and their development plans. Future studies may be needed to better examine the effects of private institutions on the production and allocation of health workers.

\section{Abbreviations}

GDP: Gross domestic product; HEl: Higher educational institutions; MOE: Ministry of Education; TCM: Traditional Chinese medicine

\section{Acknowledgements}

The authors are grateful to Sunja Kim of University of Hawaii at Manoa for her assistance in revising the manuscript.

\section{Funding}

This study was financially supported by the China Academy of Engineering (Grant No. 2013-XZ-21-3) and China Medical Board (Grant No. 11-083).

\section{Availability of data and materials}

The dataset supporting the conclusion of this article is the asset of the Ministry of Education of People's Republic of China and is of limited use. The authors are not authorized to share it to the public. Researchers who are interested in the dataset for academic purpose may contact $\mathrm{JH}$ : houjianlin@bjmu.edu.cn

\section{Authors' contributions}

QM and ZW designed the study. JH and YL conducted the data analysis and produced the first draft under the guidance of QM and ZW. JK made substantial contributions to interpreting data and revising the manuscript critically. All authors participated in editing of the final manuscript and read and approved the final manuscript.
Ethics approval and consent to participate

Not applicable

\section{Consent for publication}

Not applicable

\section{Competing interests}

The authors declare that they have no competing interests.

\section{Publisher's Note}

Springer Nature remains neutral with regard to jurisdictional claims in published maps and institutional affiliations.

\section{Author details}

'Institute of Medical Education \& National Center for Health Professions Education Development, Peking University, Beijing, China. ${ }^{2}$ School of Public Health, Peking University, Beijing, China. ${ }^{3}$ Office of Education, Peking University Health Science Center, Beijing, China. ${ }^{4}$ University of Michigan Medical School, Ann Arbor, MI, United States of America. ${ }^{5}$ China Center for Health Development Studies, Peking University, No. 38 Xueyuan Road, Beijing 100083, China.

Received: 15 November 2017 Accepted: 13 August 2018

Published online: 22 August 2018

\section{References}

1. Frenk J, Chen L, Bhutta ZA, et al. Health professionals for a new century: transforming education to strengthen health systems in an interdependent world. Lancet. 2010;376(9756):1923-58.

2. Mullan F, Frehywot S, Omaswa F, et al. Medical schools in sub-Saharan Africa. Lancet. 2011;377(9771):1113-21.

3. Association of American Medical Colleges. 2013 Tables and graphs - medical school revenues. http://www.aamc.org/data/finance. Accessed 15 Oct 2015.

4. Tokuda Y, Hinohara S, Fukui T. Introducing a new medical school system into Japan. Ann Acad Med Singap. 2008;37(9):800-2.

5. Anekwe L. Concerns raised over the UK's first private medical school. Lancet. 2013:382(9904):1545.

6. Qin YJ. Origins of higher western medical education in China (1840-1919). The Third Military University.2007. http://kns.cnki.net/KCMS/detail/detail. aspx? $\mathrm{dbcode}=C M F D \& d b n a m e=C M F D 2009 \&$ filename $=2009022605$. $n$ h \&uid $=$ WEEvREcwSIJHSIdRa1FhdkJkcGp4Wh4ZDF2czZYQVZIUDRhZ2RWM2xyWT0= \$9A4hF_YAuvQ5obgVAqNKPCYCEjKensW4ggl8Fm4gTkoUKalD8j8gFw!!\&v= 
MDMwOTJUM3FUcldNMUZyQ1VSTDJIWnVab0Z5cm5WTHJPVjEyNOY3TzZITm ZNcXBFYIBJUjhlWDFMdXhZUzdEaDE=. Accessed 7 Nov 2017 (in Chinese).

7. Ke $Y$, Lin $H Q$, Hou JL, et al. Reorientation of health professional education reform in China for the 21st century: challenges, issues, and countermeasures. In: Ke Y, editor. Reorientation of health professional education reform in China for the 21st century. Beijing: China:Peking University Medical Press; 2014. p. 3. (in Chinese).

8. The State Council of the People's Republic of China. Regulations on the Running of Educational Institutions with Social Resources. No. 226 Decree of the State Council of the People's Republic of China. 1997. http://www.people com.cn/zgrdxw/faguiku/jy/F44-1010.html. Accessed 7 Nov 2017. (in Chinese).

9. Wu WM, Ji XH, Huang RY. Study about the development of private higher medical colleges in China. Res in Med Edu. 2009;8(9):1039-41. https://doi. org/10.3760/cma.j.issn.2095-1485.2009.09.002. (in Chinese)

10. The Central People's Government of the People's Republic of China. Private Education Promotion Law of the People's Republic of China. 2002. http:// www.gov.cn/banshi/2005-05/25/content_933.htm. Accessed 4 Oct 2016. (in (hinese).

11. Zhang $H$, Hu WM, Huang $M$, et al. Research on current situation and transformation of the school-running modes in medical independent college. Northwest Med Edu. 2013;21(5):873-5. https://doi.org/10.13555/j. cnki.c.m.e.2013.05.065. (in Chinese)

12. Ministry of Education of the People's Republic of China. Measures for the establishment and administration of independent schools 2008. http://www.gov. cn/fffg/2008-03/07/content_912242.htm. Accessed 3 Nov 2017. (in Chinese).

13. Liu Q. Human body anatomy teaching in private medical college. J Bran Camp First Mil Med Univ. 2005;28(1):12-3. (in Chinese)

14. Li ZC, Gong PQ. A wonderful flowers in private education of health professionals. Guangming Daily. 2006;7 http://news.sina.com.cn/o/2006-0303/01158346978s.shtml. Accessed 6 Sept 2016. (in Chinese)

15. Yan LS, Gao SM, Shi ZS, et al. A monument in private education of health professionals. Henan Daily. 2011;5 http://newpaper.dahe.cn/hnrb/html/201107/05/content_537965.htm. Accessed 6 Sept 2016. (in Chinese)

16. Liu CL, Gong PQ. Suggestions on innovative training modes in private medical colleges. China Higher Med Edu. 2006;08:43-6. https://doi.org/10. 3969/j.issn.1002-1701.2006.08.021. (in Chinese)

17. Xie $Y X, X u M X$. Research on selection of part-time teacher in the private medical colleges. Value Engineering. 2010:05:170-2. https://doi.org/10.3969/ j.issn.1006-4311.2010.05.097. (in Chinese)

18. Zhang XY, Zhang XR, Yu JQ. Research on systematic management of independent medical colleges based on sources of teachers. J of Hubei Correspondence Univ. 2015;28(13):19-20. https://doi.org/10.3969/j.issn.16715918.2015.13-010. (in Chinese)

19. Liu CL, Fan YF. Teaching quality management and assessment in private medical colleges. China Higher Med Edu. 2006;10:36-7. https://doi.org/10. 3969/j.issn.1002-1701.2006.10.017. (in Chinese)

20. Shen XH. Analysis of the status quo of allocation of educational resources for non-governmental ordinary colleges and universities in Beijing. J Zhejiang Shuren Univ. 2009;9(1):24-7. (in Chinese)

21. Zhang Q, Pan Z, He LY. Exploration on the current status and reform of teaching management in independent medical schools. Contemporary Med. 2014;20(35):163-4. https://doi.org/10.3969/j.issn.1009-4393.2014.35.116. (in Chinese)

22. Liu Y. Discussions on clerkship for medical students of private colleges. News Universe (article ed). 2008:06:180-2. (in Chinese)

23. Chen YH, Liu Y. Study on clerkship for medical students of private colleges. Guiding J of Traditional Chinese Med Pharm. 2009;15(5):116-7. https://doi. org/10.13862/j.cnki.cn43-1446/r.2009.05.06. (in Chinese)

24. Wu WM, Ji XH, Liu JB. Discussions and suggestions on promoting the development of private colleges and schools in education of health professionals. Jiangsu Higher Edu. 2009;2:60-2. https://doi.org/10.3969/j.issn. 1003-8418.2009.02.019. (in Chinese)

25. Yang HS, Li XZ. Could a private medical school that violates regulations produce qualified physicians? China Business Herald. 2005; http://bianke.cnki. net/Web/Article/ZGSB20050517ZZZ1.html. Accessed 7 Nov 2017 (in Chinese)

26. Li WX. Current status of and suggestions on the employment of graduates from independent medical colleges. J Changchun Univ of Sci and Tech. 2013;8(3):90-1. (in Chinese)

27. Yan CS. The superficial analysis of influencing factors of teaching base construction of private medical colleges and universities. Value Engineering. 2011; 28:176-7. https://doi.org/10.3969/j.issn.1006-4311.2011.28.120. (in Chinese)
28. Liao HY. Stuy on employment issues facing medical graduates of an independent school from a livelihood perspective: using Xiangxi School of Hunan University of Chinese Medicine as an example. Hunan University of Chinese Medicine; 2015. http://kns.cnki.net/KCMS/detail/detail.aspx?dbcode= CMFD\&dbname $=$ CMFD201502\&filename $=1015563475$.nh\&uid $=$ WEEVRECwSIJHSIdRa1Fhb09jSnZnUzBTRjVFVENkWGZhamFEMTFONUVkMD0= \$9A4hF_YAuvQ5obgVAqNKPCYcEjK. Accessed 3 May 2016. (in Chinese).

29. Ding L, Zeng Y. Evaluation of Chinese higher education by TOPSIS and IEW-the case of 68 universities belonging to the Ministry of Education in China. China Econ Rev. 2015;36:341-58. https://doi.org/10.1016/j.chieco. 2015.05.007. (in Chinese).

30. Min W, Gu Y. Talents training mode reform and practice in independent college of Chinese medicine. Pharmaceutical Edu. 2015;31(1):5-8. https:// doi.org/10.16243/j.cnki.32-1352/g4.2015.01.002. (in Chinese)

31. Chen L, Jiang BS, He ST. Analysis of resemblance in specialty setting among independent colleges: a case study based on Kangda college of Nanjing Medical University. Acta Universitatis Medicinalis Nanjing (Social Science). 2010; 4:343-6. https://doi.org/10.3969/j.issn.1671-0479.2010.04.021. (in Chinese)

32. Yao X, Qin W. Analysis on the current status and issues in China's higher education of health professionals. Northwest Med Edu. 2010;18(2):218-20. https://doi.org/10.13555/j.cnki.c.m.e.2010.02.049. (in Chinese)

33. Ke M, Zhou J. Tuition for private education institutions will increase by about 30\% this fall. Changjiang Times. 2014; http://www.changjiangtimes. com/2014/08/484763.html. Accessed 5 May 2016. (in Chinese)

34. Peng H. Private universities and colleges are allowed to determine the level of tuition by themselves and most institutions increased tuition. Huashang Daily. 2015; http://news.hsw.cn/system/2015/0803/285512.shtml. Accessed 5 May 2016. (in Chinese)

35. Lei Z. Supervision should be in place after private colleges and universities are allowed to determine the level of tuition by themselves. Ren Min Wang. 2015; http://opinion.people.com.cn/n/2015/0726/c159301-27360567.html. Accessed 5 May 2016. (in Chinese)

36. Hou JL, Luo YH, Wang ZF, et al. Study on the scale and structure of health professional education in China's colleges and universities from 1998 to 2012. Chinese J Med Edu Res. 2015;15(2):114-9, 120. https://doi.org/10.3760/ cma.jissn.2095-1485.2016.02.002. (in Chinese)

37. Bao W, Liu YH. Interregional disparities in the resources allocation of China's higher education based on the perspective of equity. Res in Edu Dev. 2009; 23:37-43. https://doi.org/10.14121/j.cnki.1008-3855.2009.23.006. (in Chinese)

38. Bao W, Liu YH. An HLM analysis of disparities in the resources allocation of China's higher education. Res in Edu Dev. 2011;19:1-7. https://doi.org/10. 14121/j.cnki.1008-3855.2011.19.007. (in Chinese).

39. Yao X. Comparative study of educational resources and developments in Xinjiang Medical University and some higher medical education institutions: Xinjiang Medical University; 2003. http://kns.cnki.net/KCMS/detail/detail. asp $x$ ?dbcode $=$ CMFD\&dbname $=$ CMFD0506\&filename $=2004137419$. nh\&uid $=$ WEEVRECwSIJHSIdRa1FhdkJkcGp4Wh4ZDF2czZYQVZIUDRhZ2RWM2xyWT0= \$9A4hF_YAuvQ5obgVAgNKPCYcEjKensW4ggl8Fm4gTkoUKalD8j8gFw!!\&v= MTYONjZZUzdEaDFUM3FUcldNMUZyQ1VSTDJIWnVab0Z5cm5Wci9NVjEyNO dySzdHZFhOcHBFYIBJUjhIWDFMdXg=. Accessed 7 Nov 2017. (in Chinese)

40. Zhang ZX, Qiao YH, Peng W. Current status and development strategies of health professionals education in Hebei province. China Higher Med Edu. 2008;2:52-5. https://doi.org/10.3969/j.issn.1002-1701.2008.02.025. (in Chinese)

41. Li Q. Hot topics on medical education. Nat Sci J Hainan Univ. 2005;23(1): 91-4. https://doi.org/10.15886/j.cnki.hdxbzkb.2005.01.020. (in Chinese)

42. Yang $L B$, Cao DP, Yang $L L$, et al. Accreditation of medical education in the world and the practice in China. Chin J Med Edu. 2010;30(5):781-3. https:// doi.org/10.3760/cma.j.issn.1673-677X.2010.05.048. (in Chinese)

43. Liang HJ, Wen DL, Tian W, et al. Comparative research of medical education accreditation between US and China. Chin J Med Edu. 2012; 32(5):790-791, 797. https://doi.org/10.3760/cma.j.issn.1673-677X.2012.05. 052. (in Chinese) 